\title{
The Dynamics of Inflation, Money Growth, Exchange Rates and Interest Rates in Ghana
}

\section{Ignatius Abasimi}

School of Economics, Northeast Normal University, Changchun, Jilin, China. abasimiignatus@gmail.com

\section{Xuan Li}

School of Economics, Northeast Normal University, Changchun, Jilin, China.

\section{Agus Salim}

School of Economics, Northeast Normal University, Changchun, Jilin, China.

\section{Long Vorlak}

School of Economics, Northeast Normal University, Changchun, Jilin, China.

\begin{abstract}
Does money supply really influence inflation in Ghana? This study investigates the dynamics of inflation, money growth, exchange rate and interest rates in Ghana from 1990-2017. The autoregressive distributed lag model (ARDL) and error correction model (ECM) were employed in the study because the studied variables were found to be integrated and co-integrated at different intensities. The results revealed that money supply has no impact on inflation in the short and long run in the study period. Exchange rate and nominal interest rate were however found to influence inflation rate significantly in both the short and long run and in the same direction. It is recommended that the Bank of Ghana should maintain a stable economic growth by establishing a rigorous pecuniary polices as well as derivatives conveyance for financial institutions in the country to act in complacence.
\end{abstract}

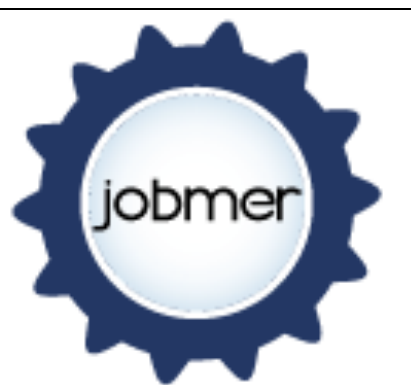
Journal of Business Management and Economic Research Vol.2, Issue.6, 2018 pp.21, 32

Doi: 10.29226/TR1001.2018.39

Keywords: Inflation, autoregressive distributed lag model, co-integration, Bank of Ghana, financial institutions. 
Ignatius Abasimi - Xuan Li - Agus Salim - Long Vorlak, 2018, Vol.2, Issue.6, pp.21-32

\section{Introduction}

The stability and growth of every economy depends on the impacts of the transmission mechanism of money supply, inflation and exchange rates and perhaps, the volatility of other financial instruments. Inflation targeting is one of the centermost underpinnings of most developing economies. The central bank of Ghana adopted this principle in 2007 were inflation was hedged at $5 \%$, however, there were short run shocks associated with its implementations. Nevertheless, inflation targeting is a flexible concept but not rigid. This measure of the Bank saw inflation dropped to significant digits (10.7\% in 2010 and 9.2\% in 2012). Inflation growth in Ghana has been quite repulsive since 1999-2018, for instance, Consumer prices in Ghana advanced 10.4 percent year-on-year in March of 2018, easing from a 10.6 percent rise in the previous month, mainly due to a slowdown in clothing and footwear and transport prices. Inflation rate in Ghana averaged 16.81 percent from 1998 until 2018, reaching an all-time high of 63 percent in March of 2001 and a record low of 0.40 percent in May of 1999.

According to Goldberg and Knetter (1997) exchange rate pass-through is the percentage change in local currency import prices resulting from a one percent change in the exchange rate between the exporting and importing countries. Exchange rate pass-through therefore is the effect (positive or negative) of exchange rates on import and export prices, consumer prices or inflation, investments as well as trade volumes. Engel and Rogers (1996) established that crossing the US-Canada border can considerably raise relative price volatility and that exchange rate fluctuations explain about one-third of the volatility increase. That is US-Canada border is an important determinant of relative price volatility even after making due allowance for the role of distance. Parsley and Wei (2001) confirmed previous findings that crossing national borders adds significantly to price dispersion.

The demand for and supply of money are the key determinants of exchange rates. Interest Rate Parity is an important concept that explains the equilibrium state of the relationship between interest rate and exchange rate of two countries. The foreign exchange market is in equilibrium when deposits of all currencies offer the same expected rate of return. The condition that the expected returns on deposits of any two currencies are equal when measured in the same currency is called the interest parity condition. It implies that potential holders of foreign currency deposits view them all as equally desirable assets, provided their expected rates of return are the same. Given that the expected return on say US dollar deposits is 4 percent greater than that on Ghana cedi deposits, all things being equal, no one will be willing to continue holding Ghana cedi deposits, and holders of Ghana cedi deposits will be trying to sell them for US dollar deposits. Krugman et al. (2012) explained that there will therefore be an excess supply of Ghana cedi deposits and an excess demand for US dollar deposits in the foreign exchange market.

Monetary growth also possesses deviance and self-correcting effects on every economy. Bawumia et al. (2003) postulates that a tightening of monetary policy through an increase in the monetary authority's official rates (or other rates that the Central Banks may see appropriate for monetary purposes) will lead to a fall in the demand for money, prices and output while the exchange rate will rise. What this means for the Ghanaian economy is that, following a contractionary monetary policy shock, interest rates rise the demand for money and output falls. In the short run, inflation rises and the real effect of interest rate hike is felt in the economy.

Available literature suggest that depreciation of a country currency is largely a monetary phenomenon, however, monetary expects associates this to short and long run shocks in the inflations dilemma. In many scenarios, monetary policy authorities have reacted vehemently to 
short-run digressions from targets, in a quick to maintain credibility. This had a damaging impact on the economy. Attempting to hit inflation targets for every year is not desirable and might not be feasible especially for a developing economy like Ghana.

Dennis \& Samuel (2015) noted that inflation is one macroeconomic variable that remains elusive to the policy makers in the country. Though the much-desired single digit level was attained in 2010, 2011 and 2012, it could not be sustained and has as expected returned to double digits and currently stands at about $10.3 \%$ at the end of the 2013 fiscal year. This trend is predicted to prevail for a while as policy makers struggle to discover the mix of policies that will control both inflation and its causal factors.

Most early empirical studies on monetary growth, inflation and exchange rates focus their studies on the patterns of prices of tradable goods to changes in exchange rates (purchasing power parity relations). This can be source from the studies of Magee $(1973,1974)$ and Dunn (1970). A handful of them also employed co-integration to established long run relationships between these economic variables (see; Engle and Granger (1987) and MacDonald (1995)). A more recent study is that of Bawumia et al. (2003) and Dennis \& Samuel (2015) they employed the structural error correction (ECM) and ARDL models in their working paper "An Investigation of the Transmission Mechanisms of Monetary Policy in Ghana from 1983 to 1999" and "inflation, exchange rates and interest rates in Ghana" respectively. Their studies established the existence of long run relationship between inflation, exchange rates, and real income. These studies failed to recognized the influence of interest rates and money supply on inflation in both the short and long run. Due to this opaque and scanty availability of empirical studies on the underlining phenomena, this study seeks to give a more thorough comprehension of the relationship between these economic variables by estimating the short and long run causality between inflation, money growth (broad money supply), exchange rates and interest rates in Ghana.

\subsection{Theoretical Framework}

In other to give a clear understanding of the empirical results of the study, it's imperative to take a glance at some of the theoretical literature on inflation, money supply, interest rates and exchange rates.

\section{The Fisher Effect}

The extent to which (percentage change) the nominal interest rate response to inflation expectations holding constant the real interest rate is termed as the Fisher Effect. Thus, when expected inflation rate rises in a percentage point the nominal interest rate also increases in the same percentage assuming real interest rates are kept constant.

$i_{t}=r_{t}^{e}+\pi_{t}^{e}$

Where $\mathrm{i}_{t}=$ nominal interest rate, $r_{t}^{e}=$ real interest rate, and $\pi_{t}^{e}=$ expected inflation.

Equation (1) is obtained by the following derivations;

$\left(1+i_{t}\right)=\left(1+r_{t}^{e}\right) \cdot\left(1+\pi_{t}^{e}\right)$

$1+i_{t}=1+r_{t}^{e}+\pi_{t}^{e}+\left(r_{t}^{e} \cdot \pi_{t}^{e}\right)$

$i_{t}=r_{t}^{e}+\pi_{t}^{e}+\left(r_{t}^{e} \cdot \pi_{t}^{e}\right)$

The term $\left(r_{t}^{e} \cdot \pi_{t}^{e}\right)$ is often minute and can therefore be eliminated. Thus, the Fisher Effect can be written as $\Delta \mathrm{i}_{t}=\Delta \pi_{t}^{e}$ which is a one-to-one relationship between nominal interest rate and expected inflation, the nominal interest rate is an observable factor in the marketplace and is usually referred to as the interest rate while the real interest rate is calculated from the observed 
interest rate and the forecasted inflation. This implies that an increase in expected inflation leads to a proportional increase in the nominal interest rate. Jareño \& Tolentino (2012) concluded that this also implies that when expected inflation is zero, nominal interest rate is equal to real interest rate, thus the cost of holding money is equal to its opportunity cost, the real returns on assets.

\section{Mundell-Tobin effect (1963-1965)}

This theory of interest rate and inflation postulate that nominal interest rates would increase less than one-to-one with respect to expected inflation. This is because in response to inflation the public would hold less in money balances and more in other assets, which would drive interest rates down. In other words, an increase in the exogenous growth rate of money increases the nominal interest rate and velocity of money but decreases the real interest rate. The importance of the Mundell-Tobin effect is that it appears as a deviation from the classical dichotomy. Mundell-Tobin is off the view that the real interest rate, would fall if inflation rose, meaning the overall effect would be that $i$ did not rise on a 1:1 basis with inflation. The reason, they said, that $r$ falls is because higher inflation means people would rather save than hold money: if more people are saving money then the real interest rate falls. Consequently, inflation rises whilst $r$ falls so $i$ does not rise at the same rate as inflation.

\section{Literature review}

Inflation is the general and persistent rise in the prices of goods and service manufactured in an economy. A couple of empirical studies has been conducted and portrays the short and long run relationship of inflation, exchange rates and interest rates. Bawumia et al (2003) noted in their studies "An Investigation of the Transmission Mechanisms of Monetary Policy in Ghana" from 1983 to 1999 that exchange rates, money supply and real income depicts the existence of a long and short run equilibrium relationship between inflation, money supply, the exchange rate, and real income. A Structural Vector Error Correction Analysis was used in their investigations.

Nortey et al. (2015) investigated the volatility and conditional relationship among inflation rates, exchange rates and interest rates using multivariate GARCH DCC and BEKK models using Ghana data from January 1990 to December 2013. The study revealed that the cumulative depreciation of the cedi to the US dollar from 1990 to 2013 is 7,010.2\% and the yearly weighted depreciation of the cedi to the US dollar for the period is $20.4 \%$. There was evidence that, the fact that inflation rate was stable, does not mean that exchange rates and interest rates are expected to be stable. Rather, when the cedi performs well on the forex, inflation rates and interest rates react positively and become stable in the long run. Their study further indicates that inflation rates, exchange rates and interest rates maintain stable mean and variance over the study period. Their study exhibits the time series forecast of volatility in inflation, exchange and interest rates for the next twelve months (2014). The exchange rates forecast indicates that there is likely to be instability in the exchange rate in 2014 . Their study however, were able to predict a partial effects of exchange rates and interest rates on inflation volatility, as of 2014 year ending inflation rate in Ghana was $17.0 \%$.

Dennis \& Samuel (2015) in their paper inflation, exchange rates and interest rates in Ghana: an autoregressive distributed lag model reveals that in the short run a percentage point increase in the level of depreciation of the Ghana cedi leads to an increase in the rate of inflation by $0.20 \%$. A percentage point increase in the level of nominal interest rates however results in a decrease in inflation by $0.98 \%$. Inflation increases by $1.33 \%$ for every percentage point increase in the nominal interest rate in the long run. An increase in inflation on the other hand increases the nominal interest rate by $0.51 \%$ which demonstrates the partial Fisher effect. A $1 \%$ increase in the interest rate differential leads to a depreciation of the Ghana cedi by approximately $1 \%$ which 
indicates the full International Fisher effect. Their studies concluded that they are short and long run relationships between inflation, exchange rates and interest rate in Ghana.

Fama E. \& Gibson (1982) also unfold that interest rates are negatively related with expected inflation in their study; inflation, real returns and capital investment. They employ the Mundell-Tobin model in their investigations, their evidence suggests that the variations in expected real returns is quite elementary to the outcome of capital expenditure processes. The maximum expected real returns varies directly with capital expenditures so as to achieve equilibrium allocations of resources between consumption and investment. This positive relation between expected real returns and real activity, that comes out of the real sector, combines with a negative relation between expected inflation and real activity, which is traced to the monetary sector, thus inducing the negative relation between expected inflation and expected real returns predicted by Mundell and Tobin.

Kandel et al. (1996), concluded in their studies that ex-ante interest rate has a negative correlation with expected inflation, this contradicts the fisher hypothesis that real rate of interest is independent of inflation. However, their studies are in confirmations with the theories of Mundell and Tobin, Stulz, and Darby and Feldstein. The study also reveals that nominal interest rates includes an inflation risk premium that is positively related to a proxy for inflation uncertainty.

Jareño \& Tolentino (2012) uses the OLS regression (in their studies; Fisher effect in the Spanish case: a preliminary study) to find out whether the variations in expected inflation rate influences nominal interest rates. Their study finds a positive and significant relationships between variations in the current expected inflation rate and variations in nominal interest rates. Namely, an increment of $100 \%$ in the inflation rate gets a nominal interest rates increment around $20 \%$, relying on the past inflation rate too. Thus, the study concludes the existence of partial fisher effect on inflation in the case of Spanish.

\section{Methodology}

The study uses time series data from the world bank and international monetary fund databases for 1990-2017 period. The variables considered in the study includes inflation rate (as the regressand at time $t$ ) which is adopted as a proxy for the average yearly inflation in Ghana, money supply which is measured as the annual percentage broad money growth, exchange rate is measured as the official exchange rate of 1Ghana cedis per US dollars, and the nominal interest rates measured as the deposit interest rate paid by commercial or similar banks for demand, time, or savings deposits (central bank's monetary policy rate). The study adopted the autoregressive distributed lag model (ARDL) approach to estimate the short and long run causality of the variables considered. This technique is adopted due to the fact that the variables had a mixture of $\mathrm{I}(0)$ and $\mathrm{I}(1)$ properties. This econometric model also makes it flexible to attached different variables with different lag-lengths as they infiltrate the model. This implies ARDL model has a reparameterization approach to co-integration of non-stationary variables and error-correction (EC) processes. The model is demonstrated as;

$$
\begin{aligned}
I N F_{t}=\beta_{0}+ & \beta_{1} I N F_{t-1}+\cdots+\beta_{Z} I N F_{t-D}+\varphi_{O} E X G_{t}+\varphi_{1} E X G_{t-1}+\cdots+\varphi_{h} E X G_{t-u} \\
& +\omega_{o} N I T_{t}+\omega_{1} N I T_{t-1}+\cdots+\omega_{J} N I T_{t-r}+\gamma_{O} M S_{t}+\gamma_{1} M S_{t-1}+\cdots+\gamma_{s} M S_{t-m}+\varepsilon
\end{aligned}
$$

Where INF is inflation rate, EXG is exchange rate depreciation, NIT is nominal interest rate, MS is money supply and $\varepsilon_{t}$ is the "noise" term which is serially independent, the model (Eq 5) is further stretch to incorporate the study variables as;

$$
\begin{gathered}
\Delta I N F_{t}=\beta_{0}+\Sigma \beta_{F} \Delta I N F_{t-F}+\Sigma \lambda_{j} \Delta E X G_{t-j}+\Sigma \psi_{k} \Delta N I T_{t-k}+\Sigma \pi_{x} \Delta E X G_{t-x}+\Sigma \phi_{g} \Delta M S \\
+\theta_{0} I N F_{t-1}+\theta_{1} E X G_{t-1}+\theta_{2} N I T_{t-1}+\theta_{3} M S_{t-1}+\mu_{t}
\end{gathered}
$$


Where $\beta_{0}$ is an intercept, $F_{F}, \lambda_{j}, \psi_{k}, \pi_{x}$ and $\phi_{g}$ are short run dynamics (coefficients), $\theta_{0}, \theta_{1}$ ,$\theta_{2}$, and $\theta_{3}$ are long run coefficients, and $\Delta$ represents first order differences, equation (6) can further be expressed as;

$$
\begin{aligned}
\Delta I N F_{t}=\beta_{0} & +\sum_{f=1}^{p} \beta_{F} \Delta I N F_{t-F}+\sum_{j=1}^{q} \lambda_{j} \Delta E X G_{t-j}+\sum_{k=1}^{m} \psi_{k} \Delta N I T_{t-k}+\sum_{x=1}^{\omega} \pi_{x} \Delta E X G_{t-x} \\
& +\sum_{\phi=1}^{n} \phi_{g} \Delta M S_{t-G}+\theta_{0} I N F_{t-1}+\theta_{1} E X G_{t-1}+\theta_{2} N I T_{t-1}+\theta_{3} M S_{t-1}+\mu_{t}
\end{aligned}
$$

After estimating equation (7), an $\mathrm{F}$ test on the null hypothesis $\mathrm{H}_{0}: \theta_{0}=\theta_{1}=\theta_{2}=\theta_{3}=0$ is carried out to ascertain whether the variables $I N F_{t-1}, E X G_{t-1}, N I T_{t-1} M S_{t-1}$ which have long run coefficients are statistically significant. If the regressors considered are statistically significant and co-integrated then an unrestricted error correction model (ECM) is used to estimate the given long run relationships among them.

\section{Results and Discussion}

\section{Configuration of Inflation, Exchange Rate, Interest Rate and Money Growth in Ghana}

Inflation in Ghana generally is quite volatile in historic times. For instance, it was as high as $116 \%$ in 1977 and further spike to $122 \%$ in 1983. It is however, quite stable in contemporary times with single digits being recorded between 2010-2012-year period. Due to the instability of the economy, its shoot up to double digits again in 2016 and 2017 recording at 17\% and 18\% respectively.

According to international Fisher relations, real interest rates are equal across the world, and hence differences in nominal interest rates are caused by differences in national inflationary expectations. Ergo, fluctuations in official exchange rate in the short run are caused by both the inflation differential and the nominal exchange rate. All things been equal, depreciation of the real exchange rate will have a significant knock on the inflation rate in the country. A decline in the rate of depreciation is ushered by a reduction in inflation. Figure 4.1 shows the relationship among the three variables.

Figure 4.1 Trend of inflation, exchange rate depreciation and interest rate in Ghana

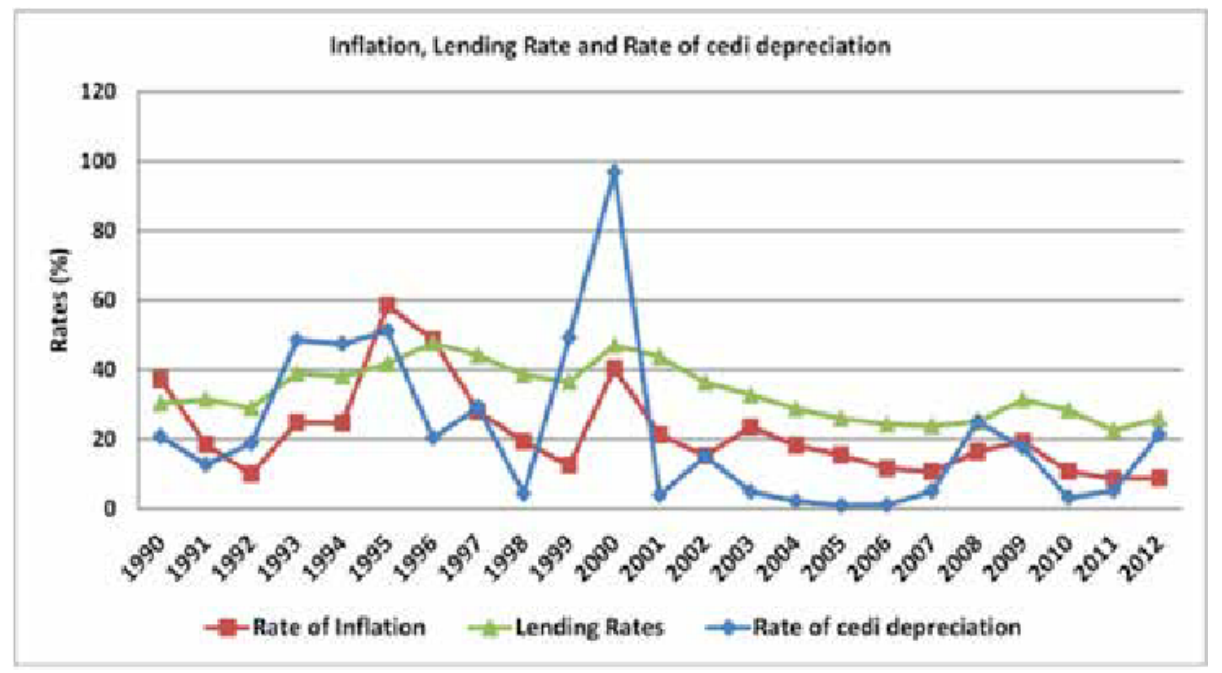

Source: ResearchGate

The money supply is one of the key monetary instruments the Bank of Ghana use to stabilize the economy as well as control inflation. The trend of money supply in Ghana displays a high growth rate level at $68.52 \%$ in 1978 and the lowest recorded in 1967 as $1.23 \%$. The high money 
supply in 1978 contributed to the high inflation in 1983 (122\%). Figure 3.2 shows the trend and money supply in Ghana in the study period.

Figure 4.2 Trend of Inflation and Money Growth in Ghana

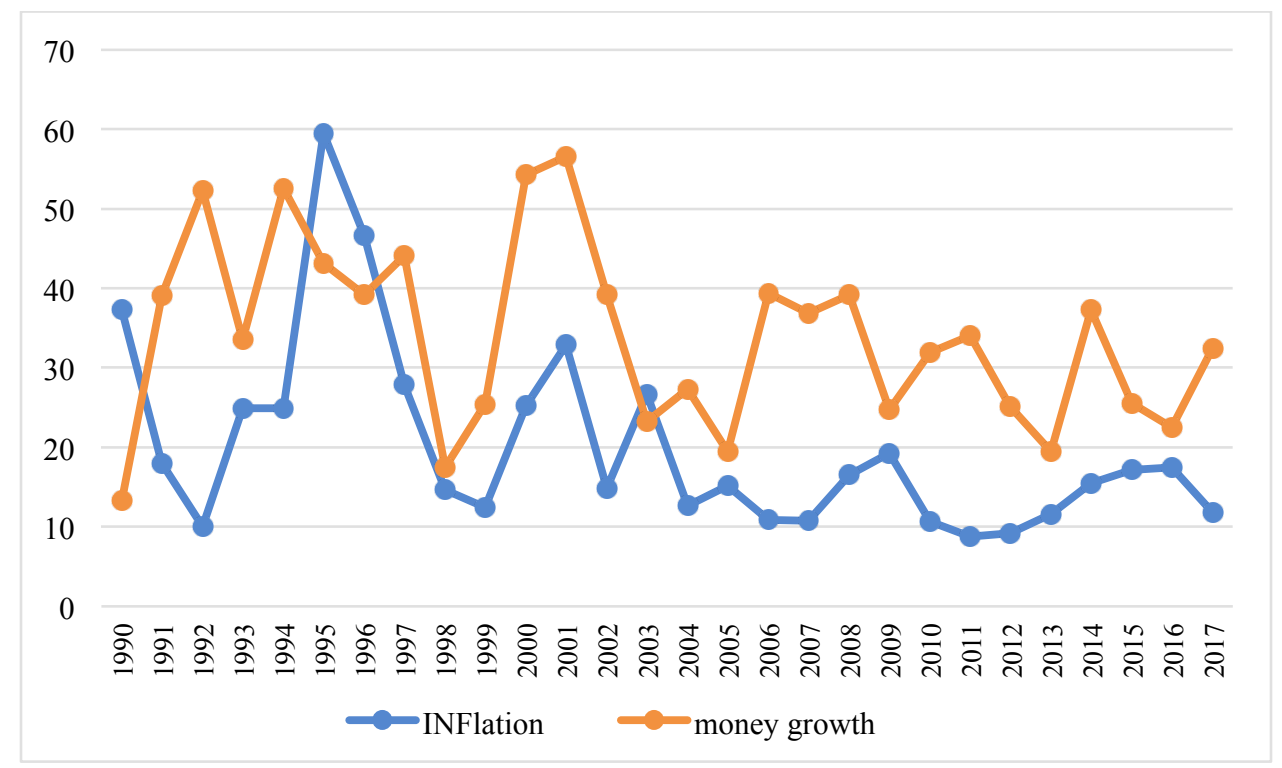

Source: Authors Construct, 2018

\section{Results of Determination Model Test}

One of the issues of time series data is that the variables are a mixture of stationary and nonstationary variables and may results to spurious estimates if OLS is applied for the analysis. Due to this, the Augmented Dickey Fuller (ADF) method is applied to test for stationarity of the variables (unit roots test) see table 4.1 below. The results portray that inflation and money supply or growth are both stationary at level and first difference. Ergo, exchange rate and nominal interest rate are both non-stationary i.e $\mathrm{I}(1)$ at level but stationary at first difference i.e $\mathrm{I}(0)$. The autoregressive distributed lag model (ARDL)was therefore suitable in this case, since the variables are integrated at different magnitudes. The (ARDL) and error correlation model (ECM) was employed to estimate the short and long run causality between the variables since they were co-integrated.

Table 4.1 Unit Root Test (ADF)

\begin{tabular}{|c|c|c|c|c|c|c|c|}
\hline Variables & $Z(t)$ & $\begin{array}{l}\text { ADF } \\
\text { Test } \\
\text { statistics }\end{array}$ & $\begin{array}{l}1 \% \\
\text { critical }\end{array}$ & $\begin{array}{l}5 \% \\
\text { critical }\end{array}$ & $\begin{array}{l}10 \% \\
\text { critical }\end{array}$ & $\begin{array}{l}\text { MacKinnon } \\
\text { (1996) one-sided } \\
\text { p-values } \\
\text { approx. for } Z(t)\end{array}$ & Decisions \\
\hline $\mathrm{INF}_{\mathrm{t}}$ & $Z(t)$ & -3.026 & -3.699 & -2.976 & -2.627 & 0.0450 & No Unit roots \\
\hline$\Delta \mathrm{INF}_{\mathrm{t}}$ & $Z(t)$ & -5.929 & -3.753 & -2.998 & -2.639 & 0.0001 & No Unit roots \\
\hline EXGt & $Z(t)$ & 3.945 & -3.699 & -2.976 & -2.627 & 1.0000 & Unit roots \\
\hline$\Delta \mathrm{EXGt}$ & $\mathrm{Z}(\mathrm{t})$ & 0,450 & -3.769 & -3.005 & -2.642 & 0.9805 & Unit roots \\
\hline $\mathrm{NIT}_{\mathrm{t}}$ & $Z(t)$ & -1.390 & -3.699 & -2.976 & -2.627 & 0.5719 & Unit roots \\
\hline$\Delta \mathrm{NITt}$ & $Z(t)$ & -4.507 & -3.724 & -2.986 & -2.632 & 0.0016 & No Unit roots \\
\hline $\mathrm{MSt}_{\mathrm{t}}$ & $Z(t)$ & -4.257 & -3.699 & -2.976 & -2.627 & 0.0026 & No Unit roots \\
\hline$\Delta \mathrm{MS}_{\mathrm{t}}$ & $Z(t)$ & -4.807 & -3.808 & -3.021 & -2.650 & 0.0012 & No Unit roots \\
\hline
\end{tabular}

Note; the ADF test statistics (absolute values of $Z(t)$ ) is compared with the critical values (absolute values) at $5 \%$ significance level. The null hypothesis is rejected if $Z(t)>5 \%$ critical value. 
The results from the unit root test shows that the variables considered are a mixture of $\mathrm{I}(0)$ and I(1). The ARDL model was applied and the residuals extracted for used in the ECM estimates. The results show that inflation, exchange rate and nominal interest rate where significant at different lags levels. (see appendix 4.1 for results).

Figures 4.3 displays the CUSUM tests and CUSUM of squares test of stability for the variables considered. It is clear from CUSUM test that the variables are quite stable for the period investigated since they do not exceed the $5 \%$ significance line. However, the CUSUM of squares shows that not all the variables are stable because they exceed the 5\% significance line. The deviation however seems to be transitory as there is a sign that the plot of CUSUM of squares test is returning back toward the criteria bands and perhaps the model is quite stable.

Figures 4.3 CUSUM Tests and CUSUM of Squares Test
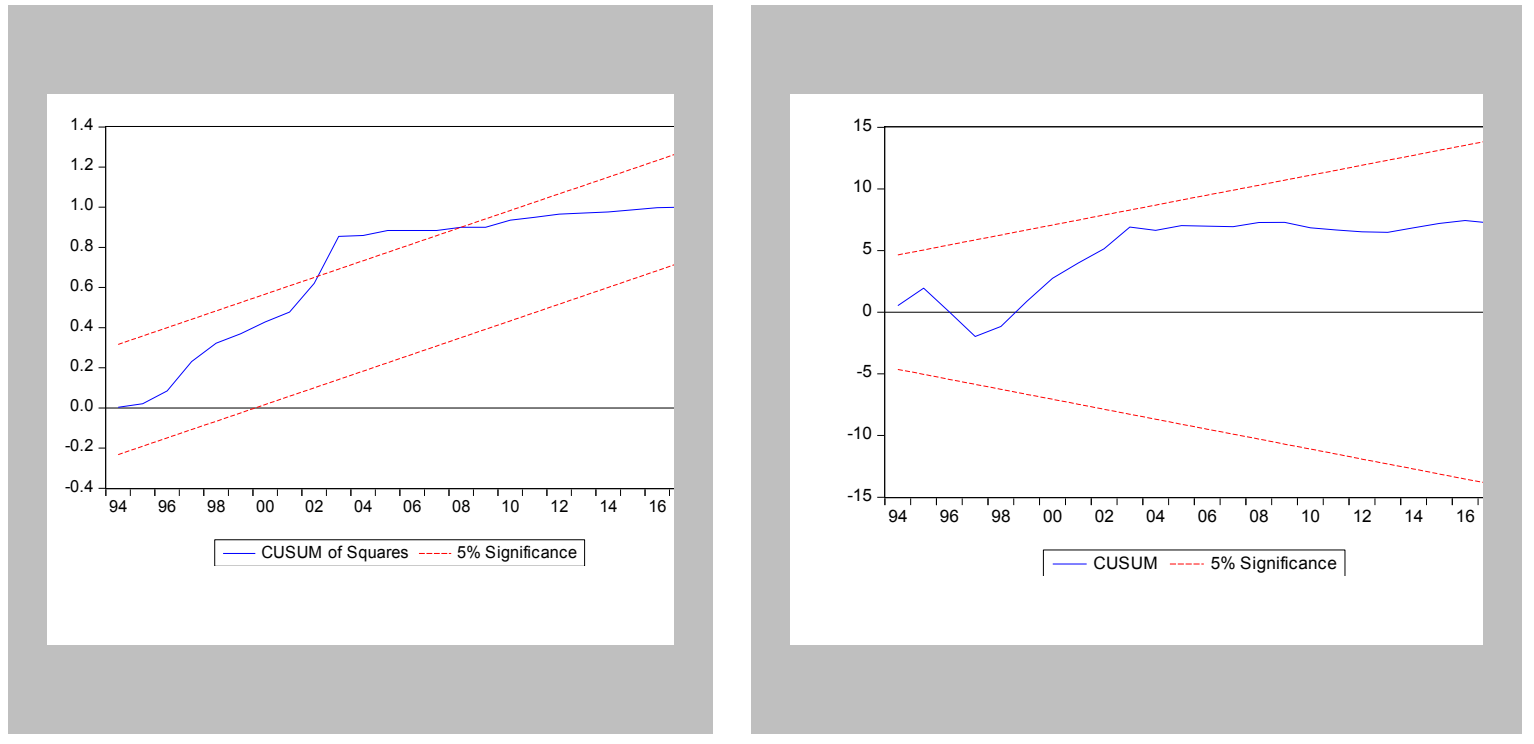

To check whether the model is stable or not and also for serial correlation, the Breusch-Godfrey Serial Correlation LM Test was carried out. Table 4.2 shows the results for the Breusch-Godfrey test for serial correlation. Since the p-value is greater than $5 \%$ significance level $(0.2355>5 \%)$, we fail to reject the null hypothesis of no serial correlation and conclude that the model and perhaps the data has no serial correlation.

Table 4.2 Breusch-Godfrey Serial Correlation LM Test

\begin{tabular}{ll}
\hline F-statistic & 0.616557 \\
Obs*R-squared & 2.892054 \\
Prob.F(4,7) & 0.5611 \\
Prob.Chi-Square(4) & 0.2355 \\
\hline
\end{tabular}

In other to determine whether the variables are co-integrated, the ARDL bound test was employed. The results of the ARDL bound test of co-integration are displayed in table 4.3. The test statistic; F-statistics has a higher value (8.52) than the upper bound critical value, 5.61 (at 1\% significance level) hence we have sufficient reasons to reject the null hypothesis of no long-run relationship at $1 \%$ significance level and perhaps the existence of cointegration among the studied variables. The error correlation model (ECM) were further applied to obtain the short (see table 4.4) and long run estimates (see table 4.5). 
Table 4.3 ARDL Bound Test of Co-integration

\begin{tabular}{lll}
\hline Variables & F-statistic & Cointegration \\
f(LINF,LEXG,LNIT,LMS) & $8.52^{* * *}$ & Cointegration \\
\hline Critical Value Bounds & & \\
(significance) & Lower Bound (I0) & Upper Bound (I1) \\
$10 \%$ & 2.72 & 3.77 \\
$5 \%$ & 3.23 & 4.35 \\
$2.5 \%$ & 3.69 & 4.89 \\
$1 \%$ & 4.29 & 5.61 \\
\hline
\end{tabular}

Table 4.4 Short run coefficients (ECM)

Dependent variable: $\ln \left(\mathrm{INF}_{\mathrm{t}}\right)$

\begin{tabular}{lllll}
\hline Variables & Coefficients & Standard Error & t-statistics & P-value \\
\hline$\Delta \ln \left(\mathrm{INF}_{\mathrm{t}-1}\right)$ & 0.922743 & 0.246010 & 3.750829 & $0.0032^{* * *}$ \\
$\Delta \ln \left(\mathrm{NIT}_{\mathrm{t}-1}\right)$ & 1.303394 & 0.213556 & 6.376331 & $0.0001^{* * *}$ \\
$\Delta \ln (\mathrm{EXGt}-1)$ & 0.194350 & 0.077927 & 2.494010 & $0.0298^{* *}$ \\
$\Delta \ln \left(\mathrm{MS}_{\mathrm{t}-1}\right)$ & 0.001355 & 0.168721 & 0.008031 & 0.9937 \\
$\mathrm{ECm}(-1)$ & -1.716035 & 0.386874 & -4.435642 & $0.0010^{* * *}$ \\
\hline
\end{tabular}

$\mathrm{R}^{2}=0.936 \mathrm{AR}^{2}=0.866$ F-statistics $=13.361 \mathrm{P}(\mathrm{F})=0.001$

Asterisk ${ }^{* *}$ and ${ }^{* *}$ indicates $1 \%$ and $5 \%$ significance levels respectively. Ln= natural log

Table 4.5 Long Run Coefficients

Dependent Variable $\ln \left(\mathrm{INF}_{\mathrm{t}}\right)$

\begin{tabular}{lllll}
\hline Variables & Coefficients & Standard Error & t-statistics & P-value \\
\hline $\ln \left(\mathrm{NIT}_{\mathrm{t}}\right)$ & 0.589285 & 0.087896 & 6.704346 & $0.0000^{* * *}$ \\
$\Delta \ln \left(\mathrm{EXG}_{\mathrm{t}}\right)$ & 0.113255 & 0.034895 & 3.245558 & $0.0078^{* * *}$ \\
$\Delta \ln \left(\mathrm{MS}_{\mathrm{t}}\right)$ & -0.137646 & 0.138442 & -0.994249 & 0.3415 \\
$\mathrm{C}$ & 1.658648 & 0.510591 & 3.248483 & $0.0078^{* * *}$ \\
\hline
\end{tabular}

\section{Discussions}

All explanations are in elasticities due to the attachment of natural logs (LN) to the variables. The short run causality was estimated by applying an unrestricted error correction technique. The ECM-1 is negative and significant at $1 \%$ level, this implies that, the speed of adjustment to equilibrium following short-run shocks is only about $1 \%$ of the disequilibrium, caused by previous period shocks, which converges back to the long-run equilibrium.

In table 4.4, the short run coefficients of nominal interest rate show that a percentage increased in nominal interest rate leads to a $1.30 \%$ rise in inflation rate in Ghana. Inflation however increased by $0.19 \%$ for every percentage increased in the exchange rate depreciation of the Ghana cedi to the US dollar. In other words, an appreciation of the US dollar to the Cedi will increase inflation by $0.19 \%$ in the short run in the country. In the long run, a percentage 
increased in the exchange rate depreciation of the cedi (GHC) to the US dollar will lead to an increased in inflation rate by $0.11 \%$ (see table 4.5 ). The percentage increased in nominal interest rate in the long run is $0.59 \%$. this implies that inflation will increased by $0.59 \%$ for every percentage point increase in nominal interest rate. Money supply or growth was however, found to have no significance effects on inflation rate in both the short and long run, however, monetary economist often attribute inflation to be a monetary phenomenon. This unexpected nature of money growth can be explained in various ways; firstly, a closely look at figure 4.2 will reveal that apart from 1994-1995 were inflation rate was higher than money supply, its (inflation) being minimal below the supply of money ever since. Nevertheless, this could be probably being attributed to Milton Freidman argument that, when people motives of demand for money is to hold more cash than to spend it, then the velocity of money supply will be constant and perhaps will not have a very significant effect on inflation. Another reason why money growth does not influence inflation in the study period could be credited to the Bank of Ghana monetary policies to tighten or cab inflation cause by increase in supply of money. Since 1983 were Ghana experienced higher inflations in historical times (122\%), which was almost always attributed to high money growth, the Bank since then has been much cautious in altering and maintaining its monetary policies hence money growth is stable and perhaps it's not seen as an inflation phenomenon.

This study is in line with Bawumia et al (2003), Dennis \& Samuel (2015) and Francisco Jareño \& Marta Tolentino (2012) findings. Dennis \& Samuel (2015) found that nominal interest rate and exchange rate depreciation of the Ghana cedis both influence inflation in the short run and long run. Their studies reveal a positive relationship between inflation and exchange rate depreciation and an inverse relationship between nominal interest rate and inflation. Bawumia et al (2003) employed co-integration and error correction model and found that inflation rate is affected by exchange rate depreciation positively. This study is also in line with the theoretical Fisher effect. The Fisher effect is based on the underlining assumption that, when the expected rate of inflation increases by a percentage point, the nominal interest rate rises by the same proportions, and this is evidenced in this studies. This is also backed by the studies of Francisco Jareño \& Marta Tolentino (2012) Their study finds a positive and significant relationships between variations in the current expected inflation rate and variations in nominal interest rates in Spanish case. Precisely, an increment of $100 \%$ in the inflation rate gets a nominal interest rates increment around $20 \%$, relying on the past inflation rate too

\section{Conclusion and Recommendation}

This study employed the autoregressive distributed lag model (ARDL) to estimate the short and long run causality or relationships among inflation, money growth, exchange rate depreciation and the nominal interest rates in Ghana. The ARDL and ECM were employed because the studied variables were found to be integrated at different intensities and co-integrated.

The results revealed that money supply has no impact on inflation in the short and long run. Exchange rate and nominal interest rate were however found to influence inflation rate significantly in both the short and long run in the same different directions. In other to promote economic growth, its sufficient for the Bank of Ghana to embark on monetary policy which aims at price stability, there is the need to coexist in harmony the indigenous and traditional interest rate-exchange rate trade-off, Goldfajn and Gupta (1998).

Due to volatility of inflation to responsiveness of interest rate and exchange rates, the Bank of Ghana should come out with more reliable but stable monetary and fiscal policies to curb both short and long run shocks of these variables. The Bank of Ghana can maintain a stable economic growth by establishing a rigorous pecuniary polices as well as derivatives conveyance for 
financial institutions in the country to act in complacence. Nevertheless, the Bank of Ghana needs to demarcate conceivable transmission mechanism for interest earnings investment securities such as T-bills and stocks so as to paved a free and stable operations of these investment sectors. This will minimize feature economics shocks in these macroeconomic variables.

\section{References}

Bawumia, M. and Abradu-Otoo, P. (2003). Monetary Growth, Exchange Rates and Inflation in Ghana: An Error Correction Analysis. Bank of Ghana Working paper, W/P BOG 2003/05.

Engle, R. F., and Granger, C. W. J. (1987). Co-integration and Error-Correction: Representation, Estimation and Testing. Econometrica, 55 (2): 251-276.

Fama, Eugene F. \& Gibbons, Michael R.(1982). Inflation, real returns and capital investment, Journal of Monetary Economics,Elsevier, vol. 9(3), pages 297-323.

Goldberg, P. K., and Knetter, M. M. (1997). Goods Prices and Exchange Rates: What Have We Learned? Journal of economic literature, 35 (3): 1243-1272.

Jareño, F., and Tolentino, M. (2012). The Fisher Effect in the Spanish Case: A Preliminary Study. Asian Economic and Financial Review, 2 (7): 841-857.

Kandel, S., Ofer, A. R., and Sarig, O. (1996). Real Interest Rates and Inflation: An Ex-Ante Empirical Analysis. Journal of Finance, 51 (1): 205-25. doi: 10.2307/2329307.

Krugman P. R., Maurice Obstfeld, Berkeley Marc J. Melitz (2012). International Economics: Theory $\mathcal{E}$ Policy, ninth edition. Pearson Publications.

Krugman, P. (1978). Purchasing Power Parity and Exchange Rates. Journal of International Economics, 8 (3): 397 - 407.

Macdonald, R. (1995). Long-Run Exchange Rate Modelling: A Survey of the Recent Evidence. International Monetary Fund Staff Papers, 42 (3): 437-389.

Magee, S. P. (1974). Import Prices in the Currency Contract Period. Brookings Papers on Economic Activity, 5 (1): 117-168.

Nchor, D., Darkwah, S. A., and LubošStřelec. (2015). Inflation, Exchange Rates and Interest Rates in Ghana: An Autoregressive Distributed Lag Model. International Journal of Scientific and Research Publications, 5 (1): 2250-3153.

Nortey, E. N., Ngoh, D. D., Doku-Amponsah, K., and Ofori-Boateng, K. (2015). Modeling Inflation Rates and Exchange Rates in Ghana: Application of Multivariate GARCH Models. Springer Plus e-Collection, 24 (4): 486. PMC. doi: 10.1186/s40064-015-0837-6. Retrieved: May 24th, 2018.

Parsley, D. C. and Wei, S. J. (2000). Explaining the Border Effect: The Role of Exchange Rae Variability, Shipping Costs, and Geography. Journal of International Economics, 55 (1): 87-105. 


\section{Appendices}

Appendix 4.1 ARDL Estimates

Dependent Variable: LINF

Method: ARDL

Date: 05/25/18 Time: 15:44

Sample (adjusted): 19942017

Included observations: 24 after adjustments

Maximum dependent lags: 4 (Automatic selection)

Model selection method: Akaike info criterion (AIC)

Dynamic regressors (4 lags, automatic): LINT LEXG BMG

Fixed regressors: $\mathrm{C}$

Number of models evalulated: 500

Selected Model: ARDL $(4,4,0,1)$

\begin{tabular}{crcrr}
\hline \hline Variable & Coefficient & Std. Error & t-Statistic & Prob. $^{*}$ \\
\hline \hline LINF(-1) & 0.204506 & 0.256113 & 0.798500 & 0.4415 \\
LINF(-2) & 0.059094 & 0.199574 & 0.296100 & 0.7727 \\
LINF(-3) & -0.627173 & 0.174539 & -3.593319 & 0.0042 \\
LINF(-4) & -0.373749 & 0.208959 & -1.788619 & 0.1012 \\
LINT & 1.294935 & 0.199373 & 6.495036 & 0.0000 \\
LINT(-1) & -1.423167 & 0.399946 & -3.558401 & 0.0045 \\
LINT(-2) & 0.758200 & 0.512882 & 1.478312 & 0.1674 \\
LINT(-3) & 0.002506 & 0.432056 & 0.005800 & 0.9955 \\
LINT(-4) & 0.411509 & 0.216965 & 1.896657 & 0.0844 \\
LEXG & -0.193463 & 0.075537 & -2.561167 & 0.0265 \\
BMG & 0.000641 & 0.005166 & 0.124078 & 0.9035 \\
BMG(-1) & -0.007966 & 0.005104 & -1.560882 & 0.1468 \\
C & 2.242968 & 0.695182 & 3.226447 & 0.0081 \\
\hline \hline R-squared & 0.938073 & Mean dependent var & 2.844199 \\
Adjusted R-squared & 0.870517 & S.D. dependent var & 0.500414 \\
S.E. of regression & 0.180068 & Akaike info criterion & -0.287791 \\
Sum squared resid & 0.356669 & Schwarz criterion & 0.350322 \\
Log likelihood & 16.45349 & Hannan-Quinn criter. & -0.118499 \\
F-statistic & 13.88577 & Durbin-Watson stat & 2.134103 \\
Prob(F-statistic) & 0.000060 & & \\
\hline \hline
\end{tabular}

*Note: p-values and any subsequent tests do not account for model selection. 